Journal of the Japanese Association for Thoracic Surgery 25 : 1459-1469, 1977. 3) Ishizaka, M.: Journal of the Japanese Assoiciation for Thoracic Surgery 25 : 1592-1601,
1977. 4) Watanabe, F., Tachiki, T., Matsuura, M., Takahashi, J., Kawakami, T., Tanabe, T.: Caldioplegia 1-6, 1982.

\title{
A-II-3 A Comparative Study on the Effect of Myocardial Protection of Multiple and Single Dose Coronary Perfusion with Bretschneider's Solution during Open Heart Surgery
}

\author{
Department of Thoracic and Cardiovascular Surgery. \\ Hanyang University Hospital. \\ Seoul, Korea
}

Kun-Ho Kim

A comparative study was made to elucidate the effect on myocardial protection of multiple and single dose coronary perfusion with Bretschneider's solution during open heart surgery.

For the present study, the patients were divided into two groups and case characteristics of group A and B were shown in the table 1 . Number of patients in group A was 30 and in group B was 70 . Infants under $10 \mathrm{~kg}$ of body weight and mortality cases were not included in this study. There were no significant differences between two groups in the distribution of age, sex and body weight. Mean age and body weight were, however, slightly lower in group $\mathrm{B}$ than group $\mathrm{A}$, since more cases of congenital anomalies were included in group $B$.

The cardioplegic solution used in this study was Bretschneider's solution at $4^{\circ} \mathrm{C}$. For the patients of group A, multiple dose of coronary perfusion with Bretschneider's solution was carried out with initial dose of $20 \mathrm{~m} l /$ $\mathrm{kg}$ of body weight. Repeated coronary perfusion was perfomed with secondary dose, one-fourth (1/4) of initiarl dose at the interval of every 20 minutes. For the patients of group $\mathrm{B}$, single dose of coronary perfusion was performed with the dose of $50 \mathrm{ml} / \mathrm{kg}$ of body weight.
Supplementary cooling was done by core cooling and topical cooling in both groups.

The component of Bretschneider's solution were as follow; $\mathrm{NaCI} 0.7 \mathrm{gm} / \mathrm{L}, \mathrm{KCl} 0.75 \mathrm{gm} / \mathrm{L}, \mathrm{MgCl}_{2}-6 \mathrm{H}_{2} \mathrm{O}$ $0.41 \mathrm{gm} / \mathrm{L}$, Procain $\mathrm{HCl} 2.0 \mathrm{gm} / \mathrm{L}$, Mannitol $43.5 \mathrm{gm} / \mathrm{L}$, PH 5.5 - 7.0,) smol $320 \mathrm{mOsm} / \mathrm{kg} \mathrm{H}_{2} \mathrm{O}$.

Myocardial damage during open heart surgery was evaluated by serum enzymes, postoperative EKG findings and necessity of defibrillator in the recovery period. Pathological changes on EKG persisted longer than 3 days following surgery was regarded as positive findings of myocardial damage. The necessity of defibrillator due to ventricular fibrillation or ventricular tachycardia were checked.

The criteria of positive findings of serum enzyme values for myocardial damage proposed by Dr. Engelman were as follow; serum glutamic oxaloacetic transaminase (SGOT): over 200 units, lactic dehydrogenase (LDH): over 900 units, creatine phosphokinase (CPK): over 800 units. We adapted this criteria for monitoring myocardial damage by changes in serum enzyme values.

The table 2 shows the difference in the incidence of positive enzyme values in group A and group B, relating 
Tab. 1 Case characteristics of group A and B

\begin{tabular}{cccccc}
\hline \multirow{2}{*}{$\begin{array}{c}\text { Nroup } \\
\text { Patient of }\end{array}$} & $\begin{array}{c}\text { Age } \\
\text { (years) }\end{array}$ & $\begin{array}{c}\text { Sex } \\
(\mathrm{M}: \mathrm{F})\end{array}$ & $\begin{array}{c}\text { Body weight } \\
(\mathrm{kg})\end{array}$ & $\begin{array}{c}\text { Diseases } \\
\text { (CHD: } \\
\text { AHD) }\end{array}$ \\
\hline A & 30 & $\begin{array}{r}2^{1 / 2}-54 \\
(21.02)\end{array}$ & $1.3: 1$ & $\begin{array}{c}11.0-65.0 \\
(37.05)\end{array}$ & $2: 1$ \\
& & & & \\
\hline \multirow{2}{*}{ B } & \multirow{2}{*}{70} & $\begin{array}{r}2^{1 / 2}-55 \\
(16.91)\end{array}$ & $1.2: 1$ & $\begin{array}{c}11.0-68.0 \\
(33.42)\end{array}$ & $2.65: 1$ \\
& & & & \\
\hline
\end{tabular}

Tab. 2 Frequency of positive enzyme values at the various aortic cross-clamping time in group $\mathrm{A}$ and $\mathrm{B}$

\begin{tabular}{|c|c|c|c|c|c|}
\hline $\begin{array}{l}\text { Aortic Cross } \\
\text { Clamping Time } \\
\text { (minute) }\end{array}$ & Group & $\mathrm{N}$ & $\begin{array}{l}\text { SGOT } \\
(\%)\end{array}$ & $\begin{array}{l}\mathrm{LDH} \\
(\%)\end{array}$ & $\begin{array}{r}\mathrm{CPK} \\
(\%)\end{array}$ \\
\hline \multirow[t]{2}{*}{$<60$} & A & 14 & 0 & 21.4 & 14.2 \\
\hline & B & 50 & 4.0 & 4.0 & 4.0 \\
\hline \multirow[t]{2}{*}{$61-90$} & A & 7 & 14.1 & 57.1 & 28.5 \\
\hline & $\mathrm{B}$ & 15 & 6.6 & 13.3 & 6.6 \\
\hline \multirow[t]{2}{*}{$>90$} & A & 9 & 33.3 & 66.6 & 33.3 \\
\hline & B & 5 & 20.0 & 20.0 & 20.0 \\
\hline \multirow[t]{2}{*}{ Over-all } & $\mathrm{A}$ & 30 & 13.3 & 43.3 & 23.3 \\
\hline & $\mathrm{B}$ & 70 & 5.7 & 7.1 & 5.7 \\
\hline \multicolumn{3}{|c|}{$\mathrm{p}$-Value } & $<0.132$ & $<0.001$ & $<0.016$ \\
\hline
\end{tabular}

to the various aortic cross clamping time. Aortic cross clamping time (ACCT) was subdivided into three groups, (1) below 60 minutes, (2) between 61 and 90 minutes, and (3) over 90 minutes.

At the ACCT below 60 minutes, the positive rate of $\mathrm{LDH}$ and CPK were significantly less in group B than in group A. Significant difference was not observed in SGOT values. At the ACCT between 61 and 90 minutes, the positive rate was markedly less in group $B$. The myocardial protection effect evaluated by enzyme values appeared to be excellent in the patients of group B. as compared with those of group A within the range of the ACCT 90 minutes.

At the ACCT over 90 minutes, the favorable myocardial protection effect observed in the patients of group $B$ was not so marked comparing with the data within the range of ACCT 90 minutes. The results reveals that myocardial protection effect evaluated by enzyme study was found to be superior in group B than in group A.
Tab. 3 Frequnecy of positive EKG and the use of defibrillator at the various aortic crossclamping time.

\begin{tabular}{ccccc}
\hline $\begin{array}{c}\text { Aortic Cross } \\
\text { Clamping Time } \\
\text { (minute) }\end{array}$ & Group & $\begin{array}{c}\text { No. of } \\
\text { Patient }\end{array}$ & $\begin{array}{c}\text { EKG } \\
(\%)\end{array}$ & $\begin{array}{c}\text { Defib- } \\
\text { rillator } \\
(\%)\end{array}$ \\
\hline$<60$ & $\mathrm{~A}$ & 14 & 0 & 35.7 \\
& $\mathrm{~B}$ & 50 & 2.0 & 22.0 \\
\hline $61-90$ & $\mathrm{~A}$ & 7 & 57.1 & 42.8 \\
& $\mathrm{~B}$ & 15 & 6.6 & 40.0 \\
\hline$>90$ & $\mathrm{~A}$ & 9 & 11.1 & 66.6 \\
& $\mathrm{~B}$ & 5 & 20.0 & 60.0 \\
\hline Over-all & $\mathrm{A}$ & 30 & 16.6 & 46.6 \\
& $\mathrm{~B}$ & 70 & 4.3 & 28.5 \\
\hline & $\mathrm{p}-$ Value & & $<0.05$ & $>0.05$ \\
\hline
\end{tabular}

This finding was statistically significant especially in the LDH and CPK values.

The table 3 shows the difference between group A and $B$ in the incidence of positive EKG findings for myocardial damage and the use of defibrillator in the recovery period. In the ACCT below 60 minutes, no significant difference was noted between two groups. In the ACCT between 61 and 90 minutes, myocardial protection effect monitored by EKG findings was definitely superior in group B, and the results evaluated by EKG findings were agreed well with the results of enzyme study. In the cases of prolonged ACCT over 90 minutes, no significant difference between two groups was noted in frequency of positive EKG findings and the use of defibrillator. As was the cases with enzyme study, EKG findings also revealed that group $\mathrm{B}$ shows better myocardial protection effect than group A. The frequency of the use of defibrillator did not show statistical difference between two groups.

With the results obtained in the present study, we established a cardioplegia and myocardial protection method that can be useful for protecting myocardium from the damage during open heart surgery. Bretschneider's solution $\left(4^{\circ} \mathrm{C}\right)$ is used as cardioplegic solution for coronary perfusion. If the ACCT is within 90 minutes, single dose coronary perfusion should be carried out with $50 \mathrm{~m} l$ of Bretschneider's cardioplegic solution 
per $\mathrm{kg}$ of body weight. If the ACCT is prolonged over 90 minutes, secondary coronary perfusion shobld be done at the ACCT of 70 minutes with one-half of the initial dose.

In addition to coronary perfusion, supplementary cooling should be done. This can be achieved by core cooling and topical cooling. The core cooling is ranged between $24^{\circ} \mathrm{C}$ and $28^{\circ} \mathrm{C}$ at rectel temperature. The topical cooling can be done by a continuous pericardial irrigation with $4^{\circ} \mathrm{C}$ normal saline.

\section{A-II-4 心筋保護法に打ける急速心停止液の臨床的意義}

$\begin{array}{rrrrrrrl}\text { 徳島大学 } & \text { 第 } 2 \text { 外科, 德島県立中央病院 } & \text { 外科*, 国立善通寺病院 } & \text { 外科** } \\ \text { 加藤 } & \text { 逸夫 } & \text { 開発 } & \text { 展之 } & \text { 新野 } & \text { 秀樹 } & \text { 藤島 } & \text { 則明 } \\ \text { 江川 } & \text { 善康 } & \text { 津田 } & \text { 洋 } & \text { 洲鎌 } & \text { 盛一 } & \text { 黑上 } & \text { 和義* } \\ & & \text { 深田 } & \text { 義夫** } & \text { 藤田 } & \text { 博** } & & \end{array}$

非血液性心管保護液の中で, 細胞内液にも似た高濃度 の電解質を含む溶液で, 多くは, one shot 注入で用い られて，極めて速な心停止をもたらすものを，とくに心 停止液とよら゙事がある. Young 液 Kirsch などがそれで ある。これらの溶液は，それ自体心筋保護作用を有し， 単独で比較的短時間の手術に用いられる事も㐫るが，そ の後に引続いて，GIK 液やいわゆる HES 液などの, 間歇的冠灌流が行われる事が多い，著者らが行ってきた 心筋保護法の主なものは, 昭和 51 年 4 月より 56 年 3 月までの Kirsch 液心停止，いわゆる HES 液の間歇的 冠灌流, topical cooling の三者併用法之, 昭和 56 年 4 月以後の To-k1 液間歇的冠灌流, topical cooling の二 者併用法とである。この両者の最大の相違点は, Kirsch 液の使用の有無によるものであり, To-k1 液はいわゆ る HES 液の HES を低分子 dextran 飞変えたもので, いわゆる HES 液との間に本質的相違は無いと考兄られ る. 今回, 対象を後天性心弁膜疾患汇限り, 三者併用法 と二者併用法とを比較して, 著者らの心筋保護法に和け るKirsch 液心停止の意義について臨床的検討を加兄た ので報告する。

なお Kirsch 液については, 幾多の批判もあるが, 泉点が明らかにしたように，one shot で心停止を得るま で注入される場合には，心筋保護上明らかに有用であり， その効果が単に溶液を冷却したための低温にのみ依存す るものではない事を強調して抽く必要がある.

\section{対象と方法}

症例は 137 例で, 前期の 87 例飞 Kirsch 液心停止, いわゆる HES 液間歇的冠灌流, topical cooling が行わ 孔, 後期の 50 例飞, To-k1 液の間歇的冠灌流之 topical cooling が行われた. 年令は前期の $44 \pm 10$ 才と後 期の $52 \pm 10$ 才，術前の心胸郭比は前期 $62.9 \%$ ，後期 $62.3 \pm 9 \%$, NYHA 分類 4 度は前期 $11.5 \%$ ，後期 $10 \%$ にみられた，単弁手術例は前期 57 例（M 弁 47， A 弁 10), 後期 23 例（M升 16， $\mathrm{A}$ 弁 $6 ， \mathrm{~T}$ 弁 1), 二弁手 術例は前期 28 例（M+ $\mathrm{T}$ 弁 17, $\mathrm{A}+\mathrm{M}$ 弁 11）, 後期 25 例 $(M+T$ 弁 19， $\mathrm{A}+\mathrm{M}$ 弁 6), 三升手術例は, 前 後期ともに 2 例ずつであった．後期例に多少の高令化が 又られ，多弁処置例が多い事の他，術前状態など両群の 症例の間飞著明な相違はみられない。

\section{成樍}

術中の大動脈遮断時間は, 前期群で $90.3 \pm 36.9$ 分, 後期群 $103.2 \pm 66.4$ 分と雨群汇有意差なく, 術後 30 日 以内の早期死は前期 5 例 $(5.7 \%)$, 後期 2 例 (4\%) で, 有意差をみない， reperfusion 時間を大動脈遮断時間で 区切ってみると遮断時間の長い程延長してくるが，両群 間に有意差なく, 平均伹は前期群 $40.5 \pm 25.7$ 分, 後期 群 $37.8 \pm 14.1$ 分であった。

蘇生時に電気的除細動を行った症例, 術中術後にカテ コラミンを必要とした 症例をみると（表 1 )，遮断時間 2 時間以内では, 遮断時間の長さの影響はみられず, 全 